\title{
Analysis of different paddy transplanting methods in northern India: Ergo - economical study
}

\section{Pragya Ojha* and Seema Kwatra}

Department of Family Resource Management, College of Home Science, G. B. Pant University of Agriculture \& Technology, Pantnagar (Uttarakhand), INDIA

*Corresponding author. E-mail: ojha.pragya063@gmail.com

Received: August 09, 2014; Revised received: September 23, 2014; Accepted: November 15, 2014

Abstract: Rice (Oryza sativa L.) production constitutes the major economic activity and a key source of employment for the rural population of India. Manual transplanting of paddy in puddle field is a very tedious job and involves lot of fatigue and drudgery. To reduce the labour demand and time consumption, power operated transplanters are also available but the poor socio- economic conditions of Indian farmers restrict them to adopt modern technology. Keeping this in view, the present study was planned to compare the economic cost and the rate of human drudgery among female farm workers, during manual hand transplanting with the power operated eight- row paddy transplanter. For the ergonomical evaluation, twenty female subjects were selected in the age group of 20-55 years. Physiological parameters like HR, energy expenditure, TCCW and PCW etc. were measured in different transplanting operations. The mean value of working heart rate was assessed to be maximum $138.32 \pm 7.67$ beats/ min in manual hand transplanting and $110.12 \pm 5.79$ beats/min in eight- row paddy transplanter. The energy expenditure rate was measured $18.40 \pm 0.95 \mathrm{~kJ} / \mathrm{min}$ in local transplanting method and reduced to $15.17 \pm 1.68 \mathrm{~kJ} / \mathrm{min}$ with paddy transplanter. TCCW was found to be $1965.5 \pm 63.66$ beats for manual transplanting of paddy and $770.58 \pm 39.93$ beats by the use of paddy transplanter whereas the PCW was calculated $227.98 \pm 22.17$ in traditional method and $85.23 \pm 2.64$ in improved method. The economic cost of mechanized transplanting was $47 \%$ less than conventional method.

Keywords: Drudgery assessment, Economical cost, Female agriculture workers, Paddy transplanting, Physiological parameters

\section{INTRODUCTION}

Rice is cultivated in 113 countries and it is the staple food of more than 50 percent population of the world. About 90 percent rice area exists in Asia (Das, 2012). India with highest area under the crop is the second largest producer of rice in the world after China but ranks 35th with respect to its productivity (Mohanty et al., 2008). The average rice yield in India is only 2.09 $\mathrm{t} / \mathrm{ha}$, as compared to $6.58 \mathrm{t} / \mathrm{ha}$ in Japan and world average of $3.91 \mathrm{t} / \mathrm{ha}$ (Dinesh and Shivay, 2007). Rice is cultivated in almost all the states of India but most of its cultivation is concentrated in the river valleys, deltas of rivers and coastal plains. The main rice producing states are Tamil Nadu, West Bengal, Andhra Pradesh, Bihar, Punjab, Orissa, Uttar Pradesh, Karnataka, Assam and Maharashtra (Mohanty et al., 2008).

During various rice cultivation operations agriculture workers are suffered with high physical strain and fatigue. In overall paddy cultivation process manual rice transplanting operation is one of the drudgery prone and back- breaking activity. Due to severe weed problem and grazing in lean season the farmers prefer transplanting than direct sowing of seeds. Generally it is found that the production increases 10-12 percent in transplanting from direct sowing. Manual paddy transplanting is a labour intensive operation which requires 200-250 man-h/ha. During peak season labourers are not available (Das, 2012).

Therefore modern agricultural technologies play a vital role in developing countries. Mechanization increases land productivity by timely completion of farm operations. It increases labour productivity and reduce drudgery of human and animals. It increases production by precision and efficient placement of inputs such as seed, fertilizer, chemicals and irrigation water. Mechanization decreases cost of production by reducing labour needed for particular operation and economy of power and other inputs (Das, 2012).

Though modernization of agriculture is taking place at a rapid pace, but the jobs attended by women remain more or less the same (Kishtwaria et al., 2009). The strength and efficiency of the female agricultural workers is 70 percent of male workers (Astrand and Rodahl, 1986). Manual rice transplantation is a tedious 
exercise but women farm workers play a chief role in this activity throughout the world. Transplanting and associated activities shared 22.3 per cent of total time spent by farmers' family women and 45.6 per cent of women wage earners (Mohanty et al., 2012). Keeping this in view, an attempt was made to compare economic cost and the ergonomic aspects of quantum of drudgery with conventional and mechanized method of paddy transplanting. This research was aimed to know the rate of physiological workload on the female agricultural workers while performing the manual paddy transplanting and reduce their physiological fatigue and human drudgery by introducing an improved technology and ergonomical evaluation both the methods.

\section{MATERIALS AND METHODS}

Selection of subject and field: The ergonomical evaluation of paddy transplanting was conducted with female agricultural workers in Tarai agro- climatic zone of Udham Singh Nagar district of Uttarakhand state, India in the month of June- July. Twenty female subjects in the age group of 20-55 years were selected because they usually attain their highest strength level between 20-45 years (Mc Ardle et al., 2001). The paddy transplanting operation was done for 7:00 A.M.12:30 P.M. and 2:00 P.M. to 5:30 P.M. For the comparison of drudgery and economical cost in mechanized and conventional method, agriculture women performed the paddy transplantation activity with manual transplanting in bending posture and power operated eight row paddy transplanter adopted from Department of Farm Machinery and Power Engineering, College of technology, GBPUA\&T, Pantnagar. The detail of specifications of power operated 8 row paddy transplanter is given in Table 1. Field women performed the continuous transplanting operations for 50 minutes and taking 10 minutes break. For the assessment of physical and physiological parameters of female workers heart rate, blood pressure, $\mathrm{VO}_{2}$ max, body mass index (BMI), age, weight, energy expenditure, total cardiac cost of work (TCCW) physiological cost of work (PCW), rate of perceived exertion and overall discomfort rating were taken into consideration. The physiological parameters were assessed at about $28-32^{\circ} \mathrm{c}$ temperature and 90-92 percent humidity. Before going to field HR rest, blood pressure, and oxygen consumption rate of the subjects were measured. After 50 minutes of continuous operation $\mathrm{HR}$ work, $\mathrm{VO}_{2}$, energy expenditure, total cardiac cost of work, physiological cost of work, rate of perceived exertion and overall discomfort rating were measured.

Calibration of subjects: The subjects were calibrated with the Harvard step stool test to determine their physical fitness index by using following formula: Physical fitness index = Duration of stepping $\times 100 /$ Sum of $1^{\text {st, }} 2^{\text {nd }}$ and $3^{\text {rd }}$ minute recovery heart rate
The physical fitness of the respondents was calculated and interpreted by using physical fitness index (PFI) score given by Verghese et al. (1994) and the respondents were ranked from poor to excellent. The resting heart rate (HR rest), oxygen consumption rate at rest $\left(\mathrm{VO}_{2}\right.$ rest $)$ and the blood pressure were measured at rest and 15 minute prior to any experiment. The blood pressure of the samples was measured by digital blood pressure monitor and the heart rate was measured by Polar heart rate monitor and recorded as HR=beat/min.

The oxygen consumption rate was calculated by following formula: $\mathrm{VO}_{2}=0.023 \times$ Body weight $(\mathrm{kg})$ $0.034 \times$ Age (years) +1.65

The body mass index of subjects was calculated by dividing square of height $\left(\mathrm{m}^{2}\right)$ to weight $(\mathrm{kg})$.

Assessment of physiological parameters: Following formula was used to calculate the total cardiac cost of work (TCCW) and physiological cost of work (PCW).

Total cardiac cost of work $=$ cardiac cost of work + cardiac cost of recovery.

$\mathrm{TCCW}=\mathrm{CCW}+\mathrm{CCR}$; where

$\mathrm{CCW}=\mathrm{AHR} \times$ Duration of activity; where

$\mathrm{AHR}=$ Avg. working HR- Average resting HR

$\mathrm{CCR}=($ Avg . recovery HR- Average resting $\mathrm{HR}) \times$ Duration.

Physiological cost of work $=$ Duration of work/TCCW Energy Expenditure was calculated using the formula: $\mathrm{EE}(\mathrm{Kj} / \mathrm{min})=0.159 \times \mathrm{HR}($ beats $/ \mathrm{min})-8.72$

Overall discomfort rating (ODR): ODR was measured on a 10-point visual analogue scale (0- no discomfort, 10-extreme discomfort) that is an adoption of a technique developed by Corlett and Bishop (1976). A scale of $70 \mathrm{~cm}$ length was fabricated having 0 to 10 digit marked on it equidistantly. A movable pointer was provided to indicate the rating. At the end of each trial, the subjects were asked to indicate their overall discomfort rating on the scale.

Rate of perceived exertion: The category scale with ratio properties for intermodal and inter individual comparison, constructed by Borg (1980) was used to assess the rate of perceived exertion of female workers after paddy transplanting activity.

Statistical analysis: Two-sample t-test assuming unequal variances was performed among the female rice cultivators to find out whether there is any significant difference in ergonomical parameters of workers for the chosen level of significance $(\mathrm{P}<0.0001)$. Statistical analysis was performed using the statistical package IBM SPSS statistics (Version =20).

\section{RESULTS AND DISCUSSION}

The mean heart rate of subjects at rest is found in the range 70.25 to 76.50 whereas the mean value was 72.96 and the corresponding oxygen consumption was $0.16 \mathrm{l} / \mathrm{min}$. The maximum $\mathrm{VO}_{2}$ of female subjects were found to be $1.82 \mathrm{l} / \mathrm{min}$ and lies in the range 1.2-2.6. 
The mean rate of the oxygen consumption of the 20-40 years age group workers was $1.79 \mathrm{l} / \mathrm{min}$ whereas the average range of $\mathrm{VO}_{2}$ of the female workers of above 40 years was calculated as $1.34 \mathrm{l} / \mathrm{min}$. In general, it was observed that the $\mathrm{VO}_{2}$ max of female decreased with increase in age. Similar results of $\mathrm{VO}_{2}$ max of Indian female subjects were also reported earlier (Nag et al., 1988; Gite, 1996; Vidhu, 2001).

The mean body mass index (BMI) was $22.05 \mathrm{~kg} / \mathrm{m} 2$ with the range as $19.3-24.36 \mathrm{~kg} / \mathrm{m}^{2}$ that indicated that all the subjects were in normal health as per the classification given by WHO (2000). Mean rate of blood pressure was $117.5 \mathrm{mmHg} / 80 \mathrm{mmHg}$ which is normal in Indian women (Table 2).

Ergonomic evaluation of paddy transplanting: The ergonomical parameters of the female subjects changed according to the type of transplanting procedure from rest value after 50 minutes of work. These values were given in the table 3 . Physiological response parameters changed due to work represents the level of fatigue or comfort in a comparative way and according to these how much the workers can work efficiently.

Heart rate: The working heart rate (HR work) of the subjects when the paddy transplanting was performed with conventional method ranged from 123.78 to 156.45 beats/min with a mean value of $138.32 \pm 7.67$

Table 1. Specification of power operated eight row paddy transplanter.

\begin{tabular}{ll}
\hline Details & Specifications \\
\hline Type & $\begin{array}{l}\text { Single wheel driven using } \\
\text { mat type rice nursery }\end{array}$ \\
Dimensions $(\mathrm{L} \times \mathrm{W} \times \mathrm{H})$ & $2410 \times 2130 \times 1300(\mathrm{~mm})$ \\
Engine $(\mathrm{hp})$ & 4.0, air cooled diesel \\
Number of rows & 8 \\
Row spacing $(\mathrm{mm})$ & 238 \\
$\begin{array}{l}\text { Hill-to-hill spacing } \\
\text { (mm) }\end{array}$ & $100-200$ \\
Working speed $(\mathrm{km} / \mathrm{h})$ & $1.5-2.0$ \\
$\begin{array}{l}\text { Speed of travel on road } \\
\text { (km/h) }\end{array}$ & 8.24 \\
Field capacity $(\mathrm{ha} / \mathrm{h})$ & $0.13-0.20$ \\
Weight $(\mathrm{kg})$ & 320 \\
Type & Single wheel driven using \\
mat type rice nursery & $2410 \times 2130 \times 1300(\mathrm{~mm})$ \\
Dimensions $(\mathrm{L} \times \mathrm{W} \times \mathrm{H})$ & 4.0, air cooled diesel \\
Engine $(\mathrm{hp})$ & 8 \\
Number of rows & \\
\hline & \\
\hline
\end{tabular}

beats/min. The corresponding values with eight row transplanter were 100.56 to 121.65 and $110.12 \pm 5.79$ beats/ min, respectively. This showed a significant $(\mathrm{P}<0.0001)$ decrease of mean HR work by $20.38 \%$. The mean work pulse $(\Delta \mathrm{HR})$ with manual transplanting was observed to be $65.7 \pm 0.9$ beats $/ \mathrm{min}$ but reduced to $51.5 \pm 1.6$ beats/min with mechanized method; a reduction of $\Delta$ HR by $21.46 \%$. Work pulse of 40 beats/ min is the allowable limit for sustained working (Kroemer et al., 1997).

Oxygen consumption rate (OCR): OCR was found to be $1.14 \pm 0.43$ and $0.68 \pm 0.12 \mathrm{l} / \mathrm{min}$, respectively for manual and mechanized method of paddy transplanting. T-test showed a significant decrease $(40.35 \%)$ in OCR with mechanized method $(\mathrm{P}<0.0001)$. Gite and Singh (1997) reported that an OCR of $0.63 \mathrm{l} / \mathrm{min}$ and HR of 105 beats/ min for women were considered acceptable for sustained work of 8 hours with intermittent rests (Mohanty et al., 2008).

Energy expenditure rate (EER): EER with manual transplanting was observed to be $18.40 \pm 0.95 \mathrm{~kJ} / \mathrm{min}$ whereas with eight row transplanter it decreased to $15.17 \pm 1.68 \mathrm{~kJ} / \mathrm{min}(17.55 \%)$. The total cardiac cost of work (TCCW) was found to be 1965.4 and 770.58 in case of manual and mechanical method respectively. With paddy tranplanter, the TCCW reduced by $60.79 \%$. The corresponding physiological cost of work (PCW) was 227.98 and 85.23 in manual and mechanical transplanting, respectively.

Overall discomfort rating (ODR): ODR was $7.95 \pm 1.09$ and $4.15 \pm 0.65$ with manual and mechanical method respectively. ODR decreased significantly $(\mathrm{P}<0.01)$ by $47.80 \%$ with paddy transplanter. The body parts with

Table 2. Physiological parameters of selected subjects $(\mathrm{N}=20)$.

\begin{tabular}{lcc}
\hline $\begin{array}{l}\text { Physical } \\
\text { characteristics of } \\
\text { subjects }\end{array}$ & Range & Mean \pm S.D. \\
\hline Age & $(20-55)$ & $39.05 \pm 9.03$ \\
Height, cm & $(145.26-$ & $151.62 \pm 3.60$ \\
& $158.89)$ & \\
Weight, kg & $(46.36-$ & \\
& $58.32)$ & $51.11 \pm 3.34$ \\
$\mathrm{BMI}, \mathrm{Kg} / \mathrm{m} 2$ & $(19.3-24.36)$ & $22.05 \pm 1.45$ \\
$\mathrm{HR}$ rest, beats/min & $(70.24-$ & $72.96 \pm 1.91$ \\
& $76.51)$ & \\
$\mathrm{HR} \mathrm{max}, \mathrm{beats} / \mathrm{min}$ & $(176-200)$ & $188.2 \pm 7.27$ \\
$\mathrm{VO}_{2}$ rest, $1 / \mathrm{min}$ & $(0.12-0.24)$ & $0.16 \pm 0.03$ \\
$\mathrm{VO}_{2} \mathrm{Max}, 1 / \mathrm{min}$ & $(1.2-2.6)$ & $1.82 \pm 0.41$ \\
$\mathrm{Blood} \mathrm{pressure}_{(\mathrm{Sys} / \mathrm{Dias}),}^{(110 / 70-}$ & $117.5 / 80 \pm 10.6$ \\
$\mathrm{mmHg} / \mathrm{mmHg}$ & $125 / 90)$ & $0 / 14.14$ \\
$\mathrm{VO}_{2} \mathrm{max}, 1 / \mathrm{min}$ & $(1.2-2.6)$ & $1.82 \pm 0.41$ \\
\hline
\end{tabular}


Table 3. Comparative ergonomical evaluation of manual transplanting with power operated eight row rice transplanter $(\mathrm{N}=20)$.

\begin{tabular}{|c|c|c|c|c|c|c|c|}
\hline \multirow[t]{2}{*}{$\begin{array}{l}\text { Ergonomical } \\
\text { parameters }\end{array}$} & \multicolumn{2}{|c|}{$\begin{array}{l}\text { Manual rice } \\
\text { transplanting }\end{array}$} & \multicolumn{2}{|c|}{$\begin{array}{l}\text { Eight row paddy } \\
\text { transplanter }\end{array}$} & \multirow[t]{2}{*}{$\begin{array}{c}\% \\
\text { Decrease }\end{array}$} & \multirow[t]{2}{*}{ t cal } & \multirow[t]{2}{*}{ P value } \\
\hline & Range & Mean \pm S.D. & Range & Mean \pm S.D. & & & \\
\hline $\begin{array}{l}\text { HR work } \\
\text { (beats/min) }\end{array}$ & $\begin{array}{c}(123.78- \\
156.45)\end{array}$ & $138.32 \pm 7.67$ & $\begin{array}{c}(100.56- \\
121.65)\end{array}$ & $110.12 \pm 5.79$ & 20.38 & $13.12 * *$ & $<0.0001$ \\
\hline $\begin{array}{l}\text { Work pulse } \\
\text { (beats/min) }\end{array}$ & $(59.8-70.8)$ & $65.7 \pm 0.9$ & $(45.3-59.5)$ & $51.6 \pm 1.6$ & 21.46 & $34.34 * *$ & $<0.0001$ \\
\hline $\begin{array}{l}\mathrm{VO}_{2} \text { work } \\
(1 / \mathrm{min})\end{array}$ & $(0.69-1.87)$ & $1.14 \pm 0.43$ & $(0.54-0.92)$ & $0.68 \pm 0.12$ & 40.35 & $4.60 * *$ & $<0.0001$ \\
\hline $\operatorname{EER}(\mathrm{kJ} / \mathrm{min})$ & (16.54-20.54) & $18.40 \pm 0.95$ & $\begin{array}{c}(11.65- \\
17.89)\end{array}$ & $15.17 \pm 1.68$ & 17.55 & $7.48 * *$ & $<0.0001$ \\
\hline TCCW & - & $1965.4 \pm 63.66$ & - & $770.58 \pm 39.93$ & 60.79 & - & - \\
\hline PCW & - & $227.98 \pm 22.17$ & - & $85.23 \pm 2.64$ & 82.61 & - & - \\
\hline $\begin{array}{l}\text { Overall } \\
\text { discomfort } \\
\text { rating }\end{array}$ & $(6.5-10)$ & $7.95 \pm 1.09$ & $(3-5.5)$ & $4.15 \pm 0.65$ & 47.80 & $13.39 * *$ & $<0.0001$ \\
\hline $\begin{array}{l}\text { Rate of } \\
\text { perceived } \\
\text { exertion }\end{array}$ & $(8-10)$ & $9.47 \pm 0.59$ & $(0.5-3)$ & $1.22 \pm 0.76$ & 87.11 & $38.34 * *$ & $<0.0001$ \\
\hline $\begin{array}{l}\text { Field } \\
\text { capacity, ha/h }\end{array}$ & $(0.003-0.015)$ & $0.004 \pm 0.002$ & $(0.13-0.20)$ & $0.165 \pm 0.02$ & 97.57 & $35.82 * *$ & $<0.0001$ \\
\hline
\end{tabular}

maximum discomfort as expressed by the operators were right upper leg, lower back, right lower leg, right foot, right upper arm and right in the descending order. The body parts discomfort was mainly due to the effort to maintain a static and bending posture while manual transplanting.

Rate of perceived exertion (RPE): RPE analysis result showed that the RPE was $9.47 \pm 0.59$ and $1.22 \pm 0.76$ with manual and mechanical method respectively. RPE decreased significantly $(\mathrm{P}<0.0001)$ by $87.11 \%$ with paddy transplanter.

Economics of transplanting methods: The daily wage of workers was taken to be Rs. 200 with ten minutes break after every fifty minutes. Actual working time was observed $7: 45 \mathrm{~h} / \mathrm{man} /$ day. For the conventional method of paddy transplantation, the labour requirement was 243-250 man-h/ha, which means for transplantation of one hectare area, 33.55 man powers is required per day. The cost of manual transplanting was 6710/ha/day. Whereas, the field capacity of 8 row power operated paddy transplanter was $0.13-0.20 \mathrm{ha} / \mathrm{h}$ (1.22 ha). The annual fixed cost and variable costs were calculated by depreciation method by taking the purchase cost, annual uses of transplanter and life of machine. Therefore, the economic cost of mechanized transplanting was $47 \%$ less than conventional method which is Rs 3557/ha. The transplanter saved $22 \%$ labour costs/day as compared to manual transplanting.

\section{Conclusion}

On the basis of above findings it was concluded that the mean heart rate of women workers in the manual method and eight-row rice transplanter was 138.32 and 110.12 beats/min, respectively. The higher values of the work pulse in manual method suggested a need for providing the women workers with adequate breaks for rest. In comparison with traditional practice, eight-row rice transplanter could reduce drudgery by 82.61 and 17.55 percent in terms of physiological cost per hectare and energy expenditure per hectare, respectively. The transplanter enables women to avoid adopting the bending posture in repetitive motion required in the traditional method. The economic cost of mechanized transplanting was Rs $3557 /$ ha, which is $47 \%$ less than conventional method. This study also highlighted that due to high level of physiological workload during manual method of paddy transplanting, maximum farm women suffered from the work related disorders and which decreases their performance on the field. In this study it was recommended that for the significant reduction of the physiological workload and human drudgery, there is dire need to create awareness about the use of |mechanized method of paddy transplantation, among the farmers of northern India, who are usually involved in conventional and manual method of transplanting.

\section{ACKNOWLEDGEMENTS}

The authors wish to acknowledge the Indian Council of Agricultural Research, New Delhi, India and G. B. Pant University of Agriculture and Technology, Pantnagar, Uttarakhand, India for providing funds and facility for the conduct of the research. 


\section{REFERENCES}

Astrand, P.O. and Rodahl, K. (1986). A Textbook of work physiology. Mc. Graw Hill, .New York.

Borg, G. (1980). Acategory scale with ratio properties for intermodal and interindividual comparisions. In Proceedings of the 22nd International Congress of Psychology. Leipzig: VEB Deutscher Verlag.

Corlett, E.N. and Bishop R.P. (1976). A technique for assessing postural discomfort. Ergonomics, 19 (2): 175 182.

Das, F.C. (2012) Status and Prospects of Mechanization in Rice. Rice Knowledge Management Portal. Available at http://www.rkmp.co.in (accessed July 2014).

Gite, L.P. (1996). Some investigation on a side lever operated knapsack sprayer from mechanical and ergonomical considerations. Ph.D. thesis. Indian Institute of Technology, Kharagpur, India.

Gite, L.P. and Singh, G. (1997). Ergonomics in agricultural and allied activities in India. No. CIAE/ 97/70, Central Institute of Agricultural Engineering, Bhopal, India.

Kishtwaria, J., Rana, A. and Sood, S. (2009). Work Pattern of Hill Farm Women - A Study of Himachal Pradesh. Studies on Home and Community Science,3 (1):67-70.

Dinesh, K. and Shivay, Y.S. (2007). Sustainable crop production and food security in India. Kurukshetra, 55 (9): 11-16.

Kroemer, K.H.E., Kroemer, H.J. and Kroemer-Elbert, K.E.
(1997). Engineering Physiology, New York: Van Nostrand Reinhold.

Mc Ardle, W.D., Katch, F.I. and Katch, V.L. (2001). Exercise Physiology, 5th edition. Pennsylvania: Lippincott Williams and Wilkins publication.

Nag, P.K., Goswami, A., Ashtekar, A.P. and Pradhan, C.K. (1988). Ergonomics in sickle operation. Applied Ergonomics, 19 (3): 233-239.

Mohanty, S.K., Behera, B.K. and Satapathy, G.C. (2008). Ergonomics of farm women in manual paddy threshing. Agricultural Engineering International: the CIGR Ejournal. Manuscript MES 08 002. Vol. X.

Mohanty, S.K., Mishra J.N. and Ghosal, M.K. (2012). Ergonomical evaluation of paddy transplanting operations in Odisha. International Journal of Agriculture Engineering. 5(2):153-157.

Verghese, M.A., Saha, P.N., Bhatnagar, A. and Chauhan, M. (1994). Development of data base for occupational Workload and physical fitness status of India women. Bombay: DSA.

Vidhu, K.P. (2001). An investigation on ergonomic evaluation of selected rice forming. M.E (Agril.) thesis. Tamil Nadu Agriculture University, Coimbatore, India.

WHO (2000). Obesity: preventing and managing the global epidemic. WHO Technical Report Series No. 894. WHO, Geneva. 